\title{
An Evaluation of a Nutrition WebQuest: The Malaysian Experience
}

\author{
Lee Sheh Wui and Rohaida Mohd. Saat \\ University of Malaya, Kuala Lumpur, MALAYSLA
}

The main purpose of the present study was to develop and evaluate a WebQuest instruction on Nutrition using WebQuest template, known as NutriQuest. NutriQuest was developed to improve Form 2 students' understanding of fundamental nutrition concepts and its application in daily life, to improve critical and creative thinking skills and to enhance cooperative learning in a web-based learning environment. The specific goals of the evaluation of NutriQuest with students and science teachers were focused on: (i) suitability of content and design of the NutriQuest website, (ii) attitudes toward WebQuest instruction, and (iii) identifying the factors affecting the usage of WebQuest instruction. The qualitative-naturalistic-formative approach was adopted in this study where the focus was on programme improvement, and exploring a variety of effects on participants. Three main techniques were used to collect data; namely observations, interviews, and analysing documents. The documents used in this study were students' diaries and their learning artefacts such as worksheets and presentation materials. Based on the findings, three conclusions could be drawn from the study. They were: (i) the NutriQuest website facilitates science learning on nutrition for Form Two students, (ii) teachers and students showed positive attitudes toward WebQuest instruction in science, and (iii) the usage of WebQuest instruction was affected by several factors.

Keywords: Cooperative Learning, Programme Evaluation, Science Inquiry, WebQuest, WebBased Instruction.

\section{INTRODUCTION}

According to Dodge (1995), who is known as 'the father of the WebQuest', a WebQuest is defined as an 'inquiry-oriented' activity in which some or all of the information that learners interact with comes from resources on the Internet'. WebQuest is a useful resource to enhance students' scientific literacy. It provides topics related to school curricula such as the atom, the biosphere, climate, weather and people, the changing earth, and DNA and genes related to human disease and health, in a context of science, technology

Correspondence to: Dr. Rohaida Mohd. Saat, Senior

Lecturer in Science Education Department of

Mathematics and Science, Faculty of Education, University of Malaya, 50603 Kuala Lumpur, Malaysia.

E-mail: rohaida@um.edu.my and society for junior and senior high school students (Sun, 2003). Currently, most of the teachers are using "Rubrics for Web Lessons" at "The WebQuest Page" (Dodge, 2002) to assess both processes and products. There is a lack of evaluation that reflects the complexities of the pedagogical, technical, organisational and institutional issues that surrounds the web-based learning. Lack of in-depth evaluation about the utility and quality of technology and especially the context in which it was used could be a key reason why teacher education programme experience difficulty in making curriculum and instructional decisions to adapt or adopt technology for courses (Kumar \& Altschuld, 2002). Besides that, there is a need for qualitative evaluation on the phenomenology of web-based instruction and qualitative observational evaluation, particularly on issues like user perspective and gender or racial issues (Owston, 1999). Johnson (1995) suggests that technology educators 'engage in research that 
probes for deeper understanding rather than examining surface features.' He notes that qualitative methodologies are powerful tools for enhancing our understanding for teaching and learning.

\section{PURPOSE OF THE STUDY}

The present study is part of a larger study on designing and evaluating of nutrition WebQuest. The main purpose of this study was to evaluate a WebQuest instruction on Nutrition using WebQuest template. This WebQuest is known as NutiQuest and it was developed to improve Form 2 students' understanding of fundamental nutrition concepts and its application in daily life, to improve critical and creative thinking skills and to enhance cooperative learning in a web-based learning environment. In Malaysia, Form 2 students are students of Grade 8. In evaluation of NutriQuest with students and science teachers, only three aspects were focused:

- Content and design of the NutriQuest website

- Attitudes toward WebQuest instruction

- Factors affecting the usage of WebQuest instruction

\section{METHODOLOGY}

\section{Design of the Study}

In this research, case study technique was employed to describe the evaluation process. Utilising qualitative methods, formative evaluations can provide depth and detail about the programme's strengths and weakness, and the perceptions of programme participants and programme staffs (Patton, 1987). Naturalistic inquiry evaluation strategies are especially useful to allow the evaluator to consider any development that might be critical and important because the design is not focused into looking at only predetermined variables and outcomes. The qualitative-naturalistic-formative approach is thus especially appropriate for programmes that are developing, innovative, or changing, where the focus is on programme improvement, facilitating more effective implementation, and exploring a variety of effects on participants or in the context of this study, is the NutriQuest users.

\section{Selection of Site and Subjects}

In this study, twelve Form 2 students were chosen to participate. A total of three science teachers participated in the study. Small group evaluation is one of the most popular formative evaluation methods (Tessmer, 1993). The number of students chosen is often determined by a balanced between representativeness and practicality. The students were then formed into groups of four according to their preferences. For the purpose of identification, the groups were addressed as Group A, $\mathrm{B}$, and $\mathrm{C}$ (see Table 1). The students were labelled in numbers for each group.

The school selected for this study was a suburban private school. Majority of the students were Chinese and only few of them were Malays and Indians. The school had one computer laboratory equipped with twenty eight computers; four computers were internetconnected, one for the teacher or instructor at the front.

Table 1: Groups and Group Members

\begin{tabular}{cc}
\hline Group & Members \\
\hline A & A1, A2, A3, A4 \\
B & B1, B2, B3, B4 \\
C & C1, C2, C3, C4 \\
\hline
\end{tabular}

\section{Data Collection Methods}

Data collection methods used in this research was observation, interview, students' diaries and product analysis. The present study employed the researcher as participant as observer. Field notes were made to describe the programme setting in detail to permit the reader to visualise that setting. The central focus was on programme activities and participants' behaviour. Information about the full sequence of events, how did the participants respond or react to what was said, and their nonverbal communication were included.

The purpose of using interviews in this study were to gain in-depth information about perceptions, attitudes, behaviours, and motivations of the participants, and refining the NutriQuest lesson by understanding the needs, problems, and ways to increase participation. All interviews conducted in this study were audio-recorded in order to avoid missing any useful information. Six one-hour tapes were used in the interviews. The tapes were transcribed to obtain verbal documentation.

Students' diaries were collected and examined their opinion toward the content and design of the NutriQuest website, their attitudes toward WebQuest instruction in learning science, problems faced during the activities and their reflections on NutriQuest lesson. Some questions which served as guidelines on diary writings were also given to the participants in order to provide them with some ideas on writing the diaries. They submitted their diaries at the end of every lesson.

Students' artifacts include worksheets, and presentation materials were used to assess students' learning outcomes after they completed the NutriQuest lesson. Students' learning product were collected and examined to determine if they have achieved learning objectives of the lesson using rubrics in the Evaluation Section of NutriQuest website. 


\section{Data Analysis}

Formative evaluation of the NutriQuest served as the purpose of this study guided the analysis and reporting of the data. Therefore, the analysis of data focused on primary evaluation questions. The present study was using inductive analysis of data, meaning that the critical themes were based on the evaluation questions emerged from the data. In order to analyse the interview data, the data were first transcribed, then chunked, coded, and categorised following the guidelines by Miles and Huberman (1994). Observation field notes were written up and analysed to corroborate the patterns generated from the interviews. Students' diaries were collected at the end of every lesson. Only relevant diary entries were extracted, coded and categorised similar to the audio transcripts.

\section{FINDINGS}

\section{Content and Design of the NutriQuest Website}

Based on the responses from teachers and students, the content and design of the NutriQuest Website were categorised into the following categories, namely positive features of the NutriQuest, negative aspects of the NutriQuest.

\section{Positive Features of the NutriQuest}

There are four subcategories describe the positive features in terms of content and design of the NutriQuest Website which include interesting, facilitate learning, facilitate cooperative learning, and attractive user interface design.

\section{Interesting}

Teacher $\mathrm{T}$ and Teacher $\mathrm{Y}$ felt that using nutrition topic in the WebQuest instruction would able to generate the interest of students. The topic was closely related to their daily lives and might be part of their real life problems. This was supported by the students' responses. While the students performed the activities in the NutriQuest, they always thought about their friends who were facing those nutritional problems. This were shown in the following excerpts, 'Ya! Yee Ting, she is very thin and eats very little' (Student A1), and 'We have used Alex's case. Alex eats too little...' (Student B1 and Student B2). In addition, the teachers valued the interdisciplinary learning which involves students in applying concepts from various subjects in real world tasks. 'Students learn science, IT, maths...living skills... Like they decide ... like they want to steam or fry the food.', as stated by Teacher T.
Besides that, Teacher $\mathrm{Y}$ valued the richness of NutriQuest's activities compared to the traditional textbook methods as stipulated in the following excerpts,

I think is challenging for Form Two students compare to traditional text book way, they just get theory. But NutriQuest provide them data, and examples, may be these are real problems that they are facing now. Not just theories...

A variety of activities such as games, worksheets, analyse case studies, and create Power Point presentation had gained interest of the students in the NutriQuest lesson. Different students had different preference on the types of activities. Some students preferred to play games as stated by Student A3, 'Read from the books are sort of boring, when we search from the Web, sometimes we get some games...' Student A4 commented that 'Food Guide Pyramid game is fun and interesting.' Other students who enjoyed Nutrition Sleuth Casebook game noted that;

I like Nutrition Sleuth Casebook, it's fun and educational (Student A2). Because we can learn that if your body is lacking some nutrients then you just have to take in something that has the sources. (Student C1 and Student C2).

Some students felt that the task of analysing case study was interesting, as commented by student A4, 'Using case study to analyse is interesting'. Three students stated that they enjoyed searching information from the Internet and doing worksheets. They also found that the worksheets were very useful for their studies as noted during the interviews and in their diary entries. For example;

I like the assignment... I mean worksheet because from the worksheet I learned a lot of stuffs about nutrition, then we get to look for the websites to search for the answers. From the procedures we learned a lot of stuffs like calories, food classes, then we can go deeper into each class, it's more detail. (Student A4, Student C1 and Student C2).

On the other hand, hands-on activity such as reading food labels from their favourite foods was found interesting as stated by Student A3 in her diary: 'I learnt how to read the food label... I actually have fun finding the food label with my group members'. Besides that, from diary entries of Student C2, it was noted that she valued the opportunity to express her talent in designing creative Power Point presentation, 'I like to do the secretary's duty... preparing the Power Point, I'm having fun when creating and decorate it!'

\section{Facilitate Science Learning}

Scaffolding tools such as guiding questions, worksheets, and web resources were found useful in structuring and supporting activities in the NutriQuest. 
The guiding questions and worksheets were seen as providing structure for the assigned task, freeing teacher to play a more facilitative and less directive role through informal teaching: "You have provided a lot of information for them to read, go through before they complete the worksheets." (Teacher Y). Student A1 and Student B2 valued the usefulness of the guiding questions as a scaffolding tool in helping them to complete the tasks, as stated in the following excerpts:

Guiding questions is like giving instruction; we

know what to do in each task and each worksheet.

(Student A1)

Yes, there are links on it, help us to achieve

information that we require. (Student B2)

Pertaining to the worksheets, worksheets were found useful in helping students in acquiring some cognitive skills. Teacher T used Worksheet 3 as an example and commented that 'It's very important to teach the students how to convert kcal to kJ. They can understand any food label in packaging.' Similar to the teachers' responses, the students valued the richness of information provided in NutriQuest as noted in their diaries entries,

NutriQuest provides most of the information needed, making it a very convenient and useful website to visit. (Student A2, Student C2 and Student C4)

Most of the stuffs I need that can't be found in my textbook are all in the NutriQuest website. (Student B4).

\section{Facilitate Cooperative Learning}

All teachers agreed that the tasks in the NutriQuest lesson able to facilitate cooperative learning since the students were given four roles to play in a group and they would know their own scopes of jobs. Observations showed that the NutriQuest lesson was able to facilitate cooperative learning. As four roles were given in a group, the students learned how to carry out their roles, for example, "When I do the secretary duty... preparing the power point presentation, I'm having fun when creating it..." (Student C2). Two students stated that they learned how to lead a group as a leader, 'I learned how to separate our duties like certain people do certain jobs so that the works can be finished earlier and on time. So that we won't mess things up and there would be neat and tidy' (Student C1), and 'As a leader, I helped others in their tasks and discussed with each other' (Student A1).

There were a few cases whereby group members help each other to understand the tasks and information from the web, learned to carry out the roles, learned to lead in a group, and took on extra role when there is a need. Students A4 reflected that her group members helped each other to understand the tasks and information from the web, 'I learned how to cooperate with our members, help each other when we have trouble... since there is only one computer; we helped each other to understand the information from the websites'. The students reflected in their dairies that they helped each other when there were problems, 'I solved the problems with my friends, we discuss during school' (Student C1 and Student C4). 'I have problem in doing the slide show presentation, my group members willing to help me. I really feel thankful to them' (Student A4).

\section{Attractive User Interface Design}

With regards to the text, colour and graphics used in the NutriQuest website, the teachers and students were satisfied with the design. They commented that the text used was clear, the colours were attractive, and the graphics used were suitable and interesting. Student A3 described the website as 'It was very interesting, can attract my attention. I like the design, not like some websites only giving the words in black and white. The colours are vivid. The jumping pictures are very nice and attractive. Children under age would like it too!' and Student A1 commented that 'The colours are very attractive, clear, creative, and striking.'.

\section{Negative Aspects of the NutriQuest}

Despite of the positive features, there were a few limitations in the content and design of the NutriQuest website perceived by the teachers and students. They were some unfavourable web resources, and some unsatisfactory user interface design.

\section{Unfavourable Web Resources}

One of the unfavourable websites the participants mentioned was the Classes of Food website. Basically the participants valued that a lot of information provided by this website. However, the website was too wordy. Followings are the comments on this website, 'I think the classes of food have too much letters. Need more animations to represent the letters, so that it is more interesting and then more people will go into that site' (Student C1). 'The programme that I dislike the most is the Classes of Food because it is full of words that make me feel bored' (Student C2). Besides that, the language used in this website might be difficult for Form 2 students as commented by Teacher Y, 'A bit challenging. It's sufficient but I'm afraid that for Form 2 students, the more they read, the more they will get confused... this website; it's like Form 4 Biology'.

On the other hand, Teacher W and Teacher T were concerned about whether the information was included in Malaysian Science syllabus, 'There are difficult terms 


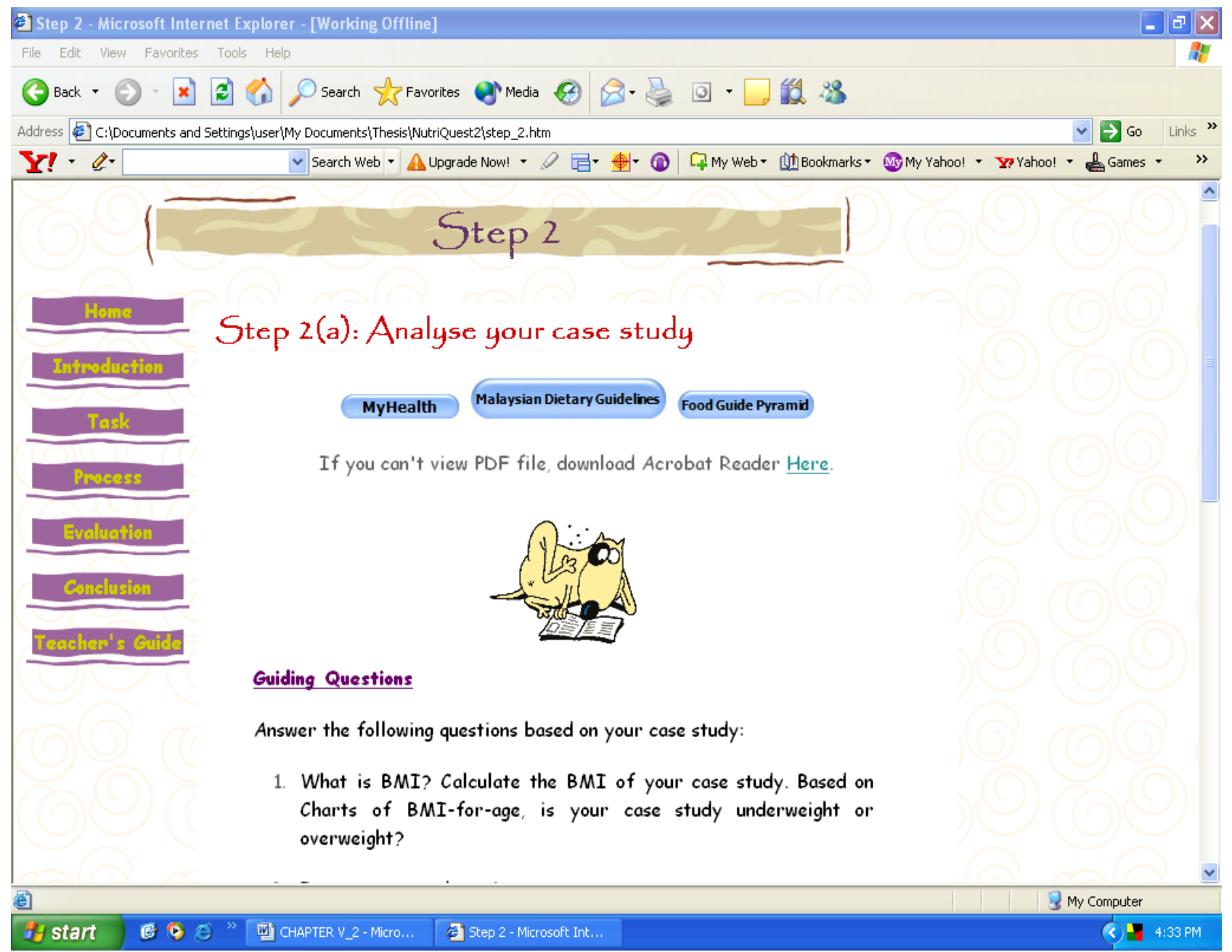

Figure 1: Display showing Position of Web Linkages

like enzymes, metabolic process...Form 2 students don't know what is enzyme yet' and 'Not too difficult... There are only 6 classes of food. Our syllabus includes fibre'.

In addition, web resources that contains too many linkages might make it complicated to read. For example Teacher $\mathrm{T}$ commented that the layout of Calorie website looked very complicated. The students reiterated Teacher T's concern, as stated by Student A3, 'I dislike the "Calorie". It has too many linkages to click'. Student C3 also noted in his dairy that, " the Calorie of Food is difficult to understand... This can be improved by doing a summary on Calorie of Food'.

\section{Unsatisfactory User Interface Design}

The first unsatisfactory user interface design was the layout of the Food Diary in the Excel format. Teacher T commented that the layout was complicated and thus suggested it to be simplified,

For the Excel, the presentation is a little bit tough; not very clear... need to see a lot of things. The layout is small and a bit complicated... May be you can simplify the food group... Overall, they will know what's lacking in the case study.

Some students suggested improving the readability of Food Diary in Excel form by inserting a legend, making it colourful, and increasing the font size. Another comment was on the linkages to web resources. Teacher $\mathrm{T}$ commented that the linkages to other web resources should be standardised so that they were on the left side vertically as illustrated in Figure 1. The presentation would make it easier for the students to identify the linkages.

Besides that, two students found it inconvenient as some web resources were only available in certain web pages. They would prefer that all linkages to web resources to be incorporated in the main menu. Student C1 commented that,

I find it very hard to browse through certain web. It's very complicated. If I'd like to look for "Classes of Food", I've to go through the steps to look for it and that's quite a lot of steps. So that's a bit complicating. I think the Classes of Food and Food Guide Pyramid should be in their own titles... Put over here... So that can find it directly. 


\section{Suggestions to Improve the NutriQuest Website}

There were a few suggestions provided by the teachers and the students so that the NutriQuest website becomes more interesting and appealing. The suggestions included ways to enhance cooperative learning, ways to arouse interest of students through driving questions, and ways to enliven the website.

\section{Ways to Enhance Cooperative Learning}

Teacher $\mathrm{T}$ suggested having more rooms for students' discussion in the NutriQuest lesson as she felt that the group members might be isolated to do their own jobs. Therefore, she suggested for not dividing their roles at the beginning and including all members in discussion for each step in the Process Section, allows them to consider ideas contributed by all members, and finally letting the person in charge to decide what to write in their presentation. For example, all group members involve in discussion and finally let the Nutritionist to make five recommendations to improve diet of the case study.

\section{Ways to Arouse Interest of Students}

Teacher $\mathrm{T}$ also provided two suggestions to make the lesson more interesting. She suggested putting a BMI calculator in the Introduction Section to engage the students in the NutriQuest lesson and the second suggestion was to add in other case studies that related to students' daily lives:

Put BMI calculator in Introduction, it's more interesting. Students may ask 'Am I too fat?', 'Why do I overweight or underweight?'... They are interested to know whether they are normal. May be if they are overweight will do Kah Beng's case [NutriQuest case study], if underweight, do Jasmine's case [NutriQuest case study]. They are concern about themselves, it's more interesting...

Other than that, you can add in other case studies such as 'Why am I always feeling tired?'... May be lack of something... What vitamins they are lacking of if their gums bleed.

From the students' perspectives, they would like to have more games and more tasks as well, as noted from the following excerpts, 'Have more games, even the children can play. For example, my sister who is in Standard 3 when she saw the games, she was attracted and looks at me how I play' (Student A2) and 'Have more tasks to find out what vitamins a person is lacking of (Student A1).

\section{Ways to Enliven the Website}

The teachers were very interested if more elements of interactivity were added into the website. For example, 'Just a suggestion, you can design something interactive to check for the answers to see whether the diet is balanced or not' (Teacher T) and 'What I mean is this, after you complete these, is it possible to have some pictures flashing, applause or cheer for them? I saw some websites like this, it just something that you can consider." (Teacher W). The students were interested to enhance the multimedia functions for the website. Their suggestion was to add in soft music into the website and user have the option to have it on or to have it off.

\section{Attitudes toward WebQuest Instruction}

The attitudes toward WebQuest instruction are categorised into positive attitudes and negative attitudes.

\section{Positive Attitudes}

Most of the teachers and students showed positive attitudes and interest toward WebQuest instruction in science as the nature of this instruction was able to provide some instructional strength particularly able to promote active learning and provide a lot of information. Besides that, they showed interest in future use of WebQuest instruction.

\section{WebQuest Promotes Active Learning}

Reflecting on the strengths of WebQuest instruction, a major concern of all teachers was that WebQuest instruction able to promote active participation of students in lessons through assigning them tasks to work on, as stated by Teacher W and Teacher Y,

WebQuest instruction encourage more self learning, have more rooms to explore, not waiting for the teachers to spoon feed them.

Students take initiative to search while taking initiative to get knowledge. It's like independent learning.

Teacher $\mathrm{T}$ added that through cooperative learning, there were more information input and students were able to remember better the knowledge gained. Student A2 perceived that WebQuest instruction would train students to be active learners and cooperate well, 'I would like to have more WebQuest because it allows you to be more proactive and encourages teamwork.' 


\section{WebQuest Provides Information}

The teachers valued the structured nature and richness of the information that can be provided in WebQuest instruction since it is linked to the Internet; it makes a lesson very convenient. For example, Teacher $\mathrm{Y}$ stated that 'A lot of information can be given at one time. They can just click and search for the things. With this [NutriQuest], students are provided with resources, teachers no longer have to photocopy materials, get a book, and spoon-feed them'. Teacher $\mathrm{T}$ added, 'WebQuest is more interesting because all the resources are given in the Web... more systematic... doesn't need to find other resources like books or articles'.

Most students preferred WebQuest instruction compared to traditional teaching methods as they can gain knowledge outside the classroom boundaries, for example Student C1 stated that, 'Of course the internet resources... that are more information compare to traditional where only teacher is teaching us, the information you get is just from the teacher. If Internet resources, information you get is from the worldwide.', 'I learned a lot from this WebQuest project. I can also help in my school studies because we did nutrition in our science chapter and this act as an extra knowledge and can help us to know more about this topic' (Student A1).

\section{Interest in Future Use}

Responding to the questions whether the participants were interested in using WebQuest instruction in future, the teachers showed positive attitudes. All the teachers would like to adopt or adapt WebQuest instruction. For example, 'Possible... but not the whole thing... may be part of it... due to limitation of time. I could do this as a project, but not that many steps. I will emphasise on building analysing skills, interpreting... the skills are quite lack of among the students...' (Teacher W). Teacher T preferred to have a mixture of classroom teaching and WebQuest activities, 'I will give the basic knowledge by teaching, may be adopting NutriQuest from Step 2 onwards... Another topic in Form 2 which is suitable to do a WebQuest is Biodiversity. Students can classify animals and plants... They can do research about animals.'

The students would like to have more WebQuest projects as well, as stipulated in the following excerpts, 'I would like to have more WebQuest project, and it is very interesting. Although it takes a lot of time but I can enjoy it every minute because it is very interesting' (Student A1). Student C2 showed her interest to introduce the WebQuest project to her other friends, 'All in all, I would like to suggest that our school would have more of these WebQuest project because it's so much more interest and fun. I love It.! I know my friends would like it too.'

\section{Negative Attitudes}

Despite of the positive attitudes toward WebQuest instruction shown among the students, minority of the students showed negative attitudes during the NutriQuest lesson included abandonment and frivolous attitudes.

\section{Abandonment}

Not all group members were cooperative and serious in completing the NutriQuest tasks. In Group B, Student B3 was absent twice during the research periods due to conjunctivitis infection. When he came back to school, he did not bother about the project at all. His group members took over his role.

\section{Frivolous Attitudes}

Besides that, some of the students viewed the WebQuest instruction as an opportunity to perform other activities such as entertainment activities and as a chance to socialise in cyberspace. From the observation, Student B1 was found checking email and other websites. During the interview, Student B2 was asked about his preference of learning method, he made a comparison by saying that 'Surfing online is a lot better than reading the textbook because by surfing online, can listen to music in your computer, play some games, check MSN, so we will study.... Using textbook we can't do all these things.' He added that 'We get to talk, get close with each other'.

Teacher W reflected that many students nowadays do not have the intrinsic motivation to study more and to think for solutions unless the teachers monitor them. He made the following comments:

Very good students who like science would like it... may be five percent. Generally, generations now like games. When they search the net, they don't go for knowledge. For Form 2 students, they don't have the intention to study more. Unless a teacher makes it as a project work and teachers force them to do.

Nowadays young people don't like to sit down and think for long. This is my concern. My point is if there is somebody to push them and guide them along the way. They can do it.

\section{Factors Affecting the Usage of WebQuest Instruction}

The present study identified three factors that could affect the usage of WebQuest instruction in the 
classroom settings; they were teacher's role, technical problems, and curriculum content.

\section{Teacher's Role}

In WebQuest instruction, teacher play an important role as a facilitator to guide students in understanding tasks, extract information from web resources, motivate students to complete the tasks, and provide technical assistance for the students. Teacher $\mathrm{Y}$ found that the tasks were quite challenging for Form 2 students. Therefore, teachers' guidance played an important role. This can be inferred from the following excerpt,

Emm... this one will take some time. They need discussion, get guidance from teachers. The teacher need to allocate some time teach them during teaching to explain to them. Every time teacher enters class should ask them whether they have any problem and then follow up (Teacher W).

During the field work session, students faced some problems in understanding the tasks; therefore they seek for the teacher's help. For example, 'We faced some difficulties in understanding the working to calculate for BMI. So we asked Miss S for some guidance' (Student A2). Some students might not seek for help though they faced problems in understanding the tasks. Therefore, teachers should always check students' understandings from time to time; consider the following excerpts during the interview session,

Student B2: Actually the Food Diary is hard to understand, I guess the information is wrong. Why two packets of nasi lemak [coconut milk rice] equal to four servings of rice, noodle?"

Student B3: Not easy to read.

Student B2: Information should have legend.

Student B4: Ya!

Researcher: If you don't understand, why didn't you ask?

Student B2: Because you never ask us to ask.

Student B3: Nobody ask us to ask.

Besides that, teacher's guidance was needed in helping students to extract information from the web resources, as commented by Teacher $\mathrm{T}$, 'This website is very detail... Teachers' guidance is very important.". As Teacher W stated at the previous section that the students might not have the intention to study more, spend time to analyse and think for solution, therefore, teachers play an important role to motivate the students in completing the tasks. In this study, teacher also played the role as a technical assistance as well. On the second day of the fieldwork, a computer in the library had some problems; the linkages did not appear after clicking them. The teacher helped the students to browse the exact websites. 'Today we've got difficulties in clicking the links in the website using the library's computer. So we asked Miss S for the exact websites to get into the particular links' noted by Student A2 and Student A4 in their diaries.

\section{Technical Problems}

Besides that, the teachers might lack of computer skills particularly in designing a website. Limited computer resources in school and technical problems could be the obstacles to implement a WebQuest instruction. Followings are the comments made by the teachers regarding the resources constraints,

All the while we are practising classroom teaching... it's hard to show them using the computer. If use one PC with large screen, projector type, very hard to guide them step by step. (Teacher W),

There are not enough resources... Internet is always down... Group members might not cooperative if they do it at home. (Teacher T).

Teacher Y expressed that lack of computer resources and software could be a problem in implementing WebQuest instruction as he stated, 'Computer also... and software must be there... and students should have computers at home.' Technical problems could affect the usability of the website. On the second day during the field work, the computer used by Group A was having some problems. Student A3 complained that, 'the computer in the library, there are some links that cannot be accessed, have to keep on refreshing but somehow still it doesn't work."

\section{Curriculum Content}

The breadth of the existing curriculum could be an inhibiting factor to affect the usage of WebQuest instruction. According to the teachers, time limitation to prepare the learning materials and to implement the lesson was the greatest problems, as what Teacher W stated, '... limited time to finish syllabus. We have not much time to explore outside the syllabus.' In addition, Teacher W described that wide coverage of curriculum had made students 'psychologically tired', 'Students nowadays have too much knowledge input, they are psychologically tired... It kills the initiative to explore more... There is no room to show their talent..' He further commented that WebQuest is more suitable when the Ministry of Education reduce the knowledge component of the curriculum, 'Good if the government cut down on the knowledge component. Students have skills of learning, so they can pick up anything easily.'

\section{DISCUSSION AND CONCLUSION}

Based on the findings, three conclusions could be drawn from the study. They were: (i) the NutriQuest 
website facilitates science learning on nutrition for Form 2 students, (ii) teachers and students showed positive attitudes toward WebQuest instruction in science, and (iii) the usage of WebQuest instruction was affected by several factors. The NutriQuest website provides students access to a breadth of resources which facilitates information exploration and knowledge construction. The NutriQuest also contains the elements to facilitate collaborative inquiry as advocated by Spitulnik and Krajcik (1998) such as meaningful and contextualised driving question, students design and conduct investigations, students produce artefacts to build and represent their understanding, and students use a multitude of technological tools to support data gathering, analysis, and presentation.

The findings of this study revealed that procedural scaffolds in the form of guiding questions, resources, templates, and worksheets supported the students as they were engaged in leaner-centred resource-based learning. The students preferred structured type of presentation with bigger subheadings, short sentences or arrange the information in a table form so that it helps them to identify and focus on the most important content. According to Hill and Hanaffin (2001), these navigational usability features of web sites may be considered procedural scaffolds. They reduce cognitive load and help learners focus on their tasks. In fact, in a web resource-based learning environment, students have to interpret and synthesise a variety of resources that may not be well organised and designed for the assigned task. These needs call for new skills in managing complex information, higher order cognitive processes (Naidu \& Bernath, 2002), and sufficient metacognitive awareness and self-regulated learning skills (Hill \& Hanaffin, 2001).

In terms of usability and design issues, lower secondary students prefer websites that are colourful, attractive, with animations or cartoons. This is similar to the usability studies with children (Gilutz \& Nielsen, 2002) that children strongly desire design elements such as animation and sound because such elements engage many senses. From this study, it was showed that games were a very engaging tool for the lower secondary students in a science inquiry web-based learning environment. According to Jonassen (1999), there must be room for learner manipulation in the problem space, such that the learners can interact, experiment or explore the phenomena being investigated.

As a part of evaluation, the teachers' and students' attitudes toward WebQuest instruction in science were examined. The most common comment revolved around the constructivist nature of WebQuests because students are involve in active learning, and cooperatively solve problems in groups. Teachers and students liked the structured nature of WebQuests because students are presented with links to all the useful information.
The findings were found similar to the study done by Perkins and McKnight (2003). In addition, $\mathrm{Ng}$ and Gunstone's study (2002) showed that the students found that the World Wide Web had a number of advantages including unlimited and up-to-date information can be accessed, easier and faster to access than books, provided motivation for independent learning and improvement of technical skills. Students preferred working in groups in WebQuest instruction in contrast to individual class wok as they could help each other in their tasks, seek and share for information. The findings was found similar to the study of Lara and Repáraz (2005) that the use of a WebQuest helps and guides group members in their investigation work and in the production of scientific videos.

Pertaining to the factors that affect the usage of WebQuest instruction, the limitation of time, resources, and computer skills remain the biggest problem in implementing the WebQuest instruction in most of the studies (Lamb \& Teclehaimanot, 2005; Perkins \& McKnight, 2003). School and national policies could influence their use of WebQuest instruction. The teachers in the present study were concerned about whether WebQuest instruction would able to cover the syllabus, and more willing to use WebQuest instruction if it is required for school-based assessment. These might be due to the reasons that teachers act to protect their influence over core elements of their work, such as covering the curriculum and maintaining their credibility (Mumtaz, 2000). However, overprotection of these core elements may set a limit to reform of the curriculum.

In the present study, teacher's role had been changed from knowledge provider to facilitator particularly in guiding students to understand the tasks, extract information from web resources, motivate students to complete the tasks, and provide technical assistance for the students. This finding was similar to Rohaida Mohd. Saat and Kamariah Abu Bakar's study (2005) who found that the teacher played five different roles in the webbased learning environment, including facilitator, moderator, technical and content specialist as well as translator to the students. In another qualitative study by Kim and colleagues (2003), the science teachers expressed that they have changed their role from a didactic one to that of a facilitator, co-learner to work with students, guide cooperative learning and encourage students to find appropriate information needed to solve a problem from websites.

In this analysis-design-evaluation process, teachers and students feedback played a major role in decisions about what changes to make in the instructional material. The evaluation of the NutriQuest website may serve as a guideline for teachers who are interested to adopt WebQuest in teaching and learning of science. However, success will depend on stakeholders, ability 
and commitment of the teachers, time constraints, schools expectations, and schools facilities.

\section{REFERENCES}

Dodge, B. (1995). Some thoughts about WebQuests. Retrieved, November, 19, 2005, from http://edweb.sdsu.edu/courses/edtec596/about_webq uests.html

Dodge, B. (2002). WebQuest taskonomy: A taxonomy of tasks. Retrieved October, 18, 2005, from http:/ / edweb.sdsu.edu/webquest/taskonomy.html

Gilutz, S. \& Nielsen, J. (2002). Usability of web sites for children: 70 design guidelines based on usability studies with kids. Retrived August, 22, 2006, from http://www.nngroup.com/reports/kids

Hill, J. \& Hannafin, M. (2001). Teaching and learning in digital environments: The resurgence of resource-based learning. Educational Technology Research and Development, 49(3), 37-52.

Johnson, S.D. (1995). Will our research hold on under scrutiny? Journal of Industrial Teacher Education, 32(3), 3-6.

Jonassen, D. H. (1999). Designing constructivist learning environment. In Reigeluth, C. M. (Ed.) Instructional design and models: A new paradigm of instructional theory (pp. 215239). Mahwah, NJ: Lawrence Erlbaum Associates.

Kim, Y., Grabowski, B. L., \& Song, H. D. (2003). Science teachers' perspectives of web-enhanced problem-based learning environment: A qualitative inquiry. (ERIC Document Reproduction Service No: ED475713)

Kumar, D. D. \& Altschuld, J. W. (2002). Complementary approaches to evaluation of technology in science education. Journal of Science Education and Technology, 11(2), 179-191.

Lamb, A. \& Teclehaimanot, B. (2005). A decade of WebQuests: A retrospective. In M. Orey, J. McClendon, \& R. M. Branch, (Eds.). Educational media and technology yearbook (Vol 30). Englewood, CO: Libraries Unlimited.

Lara, S. \& Repáraz, C. (2005). Effectiveness of Cooperative Learning: WebQuest as a Tool to Produce Scientific Videos. FORMATEX 2005. Retrieved, December, 20, 2005, from http://www.formatex.org/micte2005/294.pdf

Miles, M. B., \& Huberman, A. M. (1994). Qualitative data analysis ( $2^{\text {nd }}$ ed.). Thousand Oaks, CA: Sage Publications.

Mumtaz, S. (2000). Factors affecting teachers' use of information and communications technology: A review of the literature. Journal of Information Technology for Teacher Education, 9(3), 391-342.

Naidu, S. \& Bernath, U. (2002, July). Training the trainees in the essentials of online learning. Paper presented at the $2^{\text {nd }}$ PanCommonwealth Forum on Open Learning, South Africa, Durban.

Ng, W. \& Gunstone, R. (2002). Student's perceptions of the effectiveness of the World Wide Web as a research and teaching tool in science learning. Research in Science Education, 32(4), 489-510.

Owston, R. D. (1999). Strategies for evaluating web-based Learning. Retrieved January, 16, 2006, from http://www.edu.yorku.ca/ rowston/aera99.html
Patton, M. Q. (1987). How to use qualitative methods in evaluation. Newbury Park: Sage Publications.

Perkins, B. \& McKnight, M. (2003). What are teacher's attitudes toward Web Quests as a method of teaching? Paper presented at the Eastern Educational Research Association Conference, Hilton Head, SC, February 28-2003. Retrieved November, 23, 2005, from http://arachne.cofc.edu/faculty/Perkins/PerkinsEERA $\% 20$ WQPaper.doc

Rohaida, Mohd. Saat. \& Kamariah, Abu Bakar. (2005). Technology-based science classroom: What factors facilitate learning? Jurnal Pendidik and Pendidikan [Educator \& Education Journal], 20, 1-19.

Spitulnik, M. W. \& Krajcik, J. (1998). Technological tools to support inquiry in a science method course. The Journal of Educational Research, 17(1), 63-74.

Sun, J. H. (2003). The teacher's guide for using web-based resources in the science classroom. Retrieved, 19 July, 2006, from http://www.ioncmaste.ca/homepage/resources/web_r esources/teachingWeb/TeacherGuideBook.pdf

Tessmer, M. (1993). Planning and conducting formative evaluations: Improving the quality of education and training. London: Kogan Page.

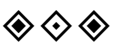

